\title{
Decline in condition of gorgonian octocorals on mesophotic reefs in the northern Gulf of Mexico: before and after the Deepwater Horizon oil spill
}

\author{
Peter J. Etnoyer ${ }^{1} \cdot$ Leslie N. Wickes ${ }^{2} \cdot$ Mauricio Silva $^{3} \cdot$ J. D. Dubick ${ }^{2}$. \\ Len Balthis ${ }^{1} \cdot$ Enrique Salgado $^{2} \cdot$ Ian R. MacDonald $^{3}$
}

Received: 6 February 2015 / Accepted: 5 October 2015/Published online: 20 October 2015

(C) The Author(s) 2015. This article is published with open access at Springerlink.com

\begin{abstract}
Hard-bottom 'mesophotic' reefs along the '40fathom' $(73 \mathrm{~m})$ shelf edge in the northern Gulf of Mexico were investigated for potential effects of the Deepwater Horizon (DWH) oil spill from the Macondo well in April 2010. Alabama Alps Reef, Roughtongue Reef, and Yellowtail Reef were near the well, situated $60-88 \mathrm{~m}$ below floating oil discharged during the DWH spill for several weeks and subject to dispersant applications. In contrast, Coral Trees Reef and Madison Swanson South Reef were far from the DWH spill site and below the slick for less than a week or not at all, respectively. The reefs were surveyed by ROV in 2010, 2011, and 2014 and compared to similar surveys conducted one and two decades earlier. Large gorgonian octocorals were present at all sites in moderate abundance including Swiftia exserta, Hypnogorgia pendula, Thesea spp., and Placogorgia spp. The gorgonians were assessed for health and condition in a beforeafter-control-impact (BACI) research design using still images captured from ROV video transects. Injury was modeled as a categorical response to proximity and time
\end{abstract}

Communicated by Ecology Editor Dr. Stuart A. Sandin

Electronic supplementary material The online version of this article (doi:10.1007/s00338-015-1363-2) contains supplementary material, which is available to authorized users.

Peter J. Etnoyer

peter.etnoyer@noaa.gov

1 NOAA Center for Coastal Environmental Health and Biomolecular Research, 219 Fort Johnson Rd., Charleston, SC 29412, USA

2 JHT, Inc., 2710 Discovery Dr., Suite 100, Orlando, FL 32826, USA

3 Florida State University, Tallahassee, FL 32306, USA using logistic regression. Condition of gorgonians at sites near Macondo well declined significantly post-spill. Before the spill, injury was observed for 4-9\% of large gorgonians. After the spill, injury was observed in $38-50 \%$ of large gorgonians. Odds of injury for sites near Macondo were 10.8 times higher post-spill, but unchanged at far sites. The majority of marked injured colonies in 2011 declined further in condition by 2014. Marked healthy colonies generally remained healthy. Background stresses to corals, including fishing activity, fishing debris, and coral predation, were noted during surveys, but do not appear to account for the decline in condition at study sites near Macondo well.

Keywords Octocoral · Gorgonian · Gulf of Mexico · Mesophotic zone $\cdot$ Oil spill $\cdot$ Health assessment

\section{Introduction}

The Deepwater Horizon oil spill released 4.3 million barrels of crude oil near $1500 \mathrm{~m}$ depth in the Gulf of Mexico over a period of $87 \mathrm{~d}$ in the spring of 2010 from the Macondo well MC 252 (McNutt et al. 2011). The oil formed a large subsurface plume and produced a large surface slick that was visible by airplane and satellite for nearly $90 \mathrm{~d}$ (NOAA 2014). The biological footprint of the DWH spill on infaunal sediments has been calculated as $148 \mathrm{~km}^{2}$ (Montagna et al. 2013), but recent studies indicate that the chemical footprint of impacted areas may be substantially larger than previously anticipated (Valentine et al. 2014). There is a potential that the biological footprint of the spill, including injury to corals, could increase with increasing search effort (Fisher et al. 2014). 
The surface oil slick from the DWH blowout persisted in the northern Gulf of Mexico for several weeks over a series of deep-water rocky reefs called the Pinnacle Trend (Fig. 1). Fishermen refer to these as the 'broken grounds' (Gittings et al. 1992). The rocky plateaus occur along the 60- to 90-m depth contours between the Mississippi Delta and Pensacola, FL. Recreational and commercial fishermen recognize these '40-fathom' reefs as good fishing habitat for snapper and grouper, conferring social and economic value on these natural resources (Prytherch 1983; ScottDenton et al. 2011).

There are nine named reefs in the Pinnacle Trend (Gardner et al. 2000). Among the largest of these are Alabama Alps Reef (AAR), Roughtongue Reef (RTR), and Yellowtail Reef (YTR), which were situated below the spill for 19-39 d (NOAA 2014). AAR (39 d), RTR (19 d), and YTR (19 d) are 57-109 km from the well. The reefs have been surveyed by remotely operated vehicle (ROV) since 1989. Two other reefs about $200 \mathrm{~km}$ to the east of the Macondo wellhead, Madison Swanson South Reef and Coral Trees Reefs, were below the slick for 0-3 d, and surveyed by ROV since 1997.

Gorgonian octocorals (sea fans), black corals, and scleractinian corals occur on all of these reefs, providing structure and refuge for small demersal fishes that are prey to larger fishes (Weaver et al. 2002). The corals contribute substantially to biodiversity in high relief areas on the reefs (Gittings et al. 1992). Suspension feeding corals are vulnerable to oil and dispersants (NOAA 2010) so these animals were considered as part of the Natural Resource Damage Assessment (NRDA) for DWH. Injury to gorgonian octocorals has been demonstrated adjacent to the wellhead, and this injury has been linked to DWH (White et al. 2012) for sites up to $22 \mathrm{~km}$ from the Macondo well (Fisher et al. 2014). Additional findings have linked numerous injured coral colonies observed in the Pinnacle Trend to exposure to DWH oil (Silva et al. 2015).

Deep-water gorgonian octocorals (Alcyonacea) and black corals (Antipatharia) are common and conspicuous in the 60-90 m 'mesophotic' depth range in the northern Gulf of Mexico, from Texas to Florida (Bayer 1961; Rezak et al. 1985; Cairns and Bayer 2009). The gorgonians are important components of deep-reef habitat because they provide structural complexity, substrate, and refuge for fish and invertebrates (Krieger and Wing 2002; Buhl-Mortensen and Mortensen 2005). The soft coral colonies grow on rocky, current-swept habitat, and prefer high relief features.

Gorgonian octocorals on the Pinnacle Trend reefs are predominantly heterotrophic suspension feeders. Their branches grow in a flabellate, reticulated (sea fan) shape with an orientation perpendicular to prevailing currents in order to maximize particle flux and rates of capture for the polyps along the branches (Peccini and MacDonald 2008). These are not technically 'mesophotic coral ecosystems' (sensu Kahng et al. 2010) because the corals are azooxanthellate, but we refer to them as 'mesophotic reefs' because they occur in the deeper portion of the photic zone.

Gorgonian octocorals and antipatharians are susceptible to exposure to water-borne toxicants because they are large, emergent epifauna with polyps adapted to straining small particles of food from the water column. The diet and prey of these heterotrophic corals consist of holoplankton-small particles of phytoplankton and zooplankton. Stable isotope studies indicate that the colonies feed on surface-originated and re-suspended photosynthetic material (Sherwood et al. 2005; Sulak et al. 2008). Transport of surface particulates to deep-water corals can be rapid (Davies et al. 2009).

The most likely mechanism for oil/dispersant exposure to the reefs would be passive or active sinking of
Fig. 1 A map showing the surface oil slick generated by the Deepwater Horizon blowout at Macondo wellhead (gray triangle), overlaid with the location of four mesophotic reefs assessed in this study (yellow circles) -Alabama Alps Reef (AAR), Roughtongue Reef (RTR), Coral Trees Reef (CTR), and Madison Swanson South Reef (MSSR). Yellowtail Reef is adjacent to RTR

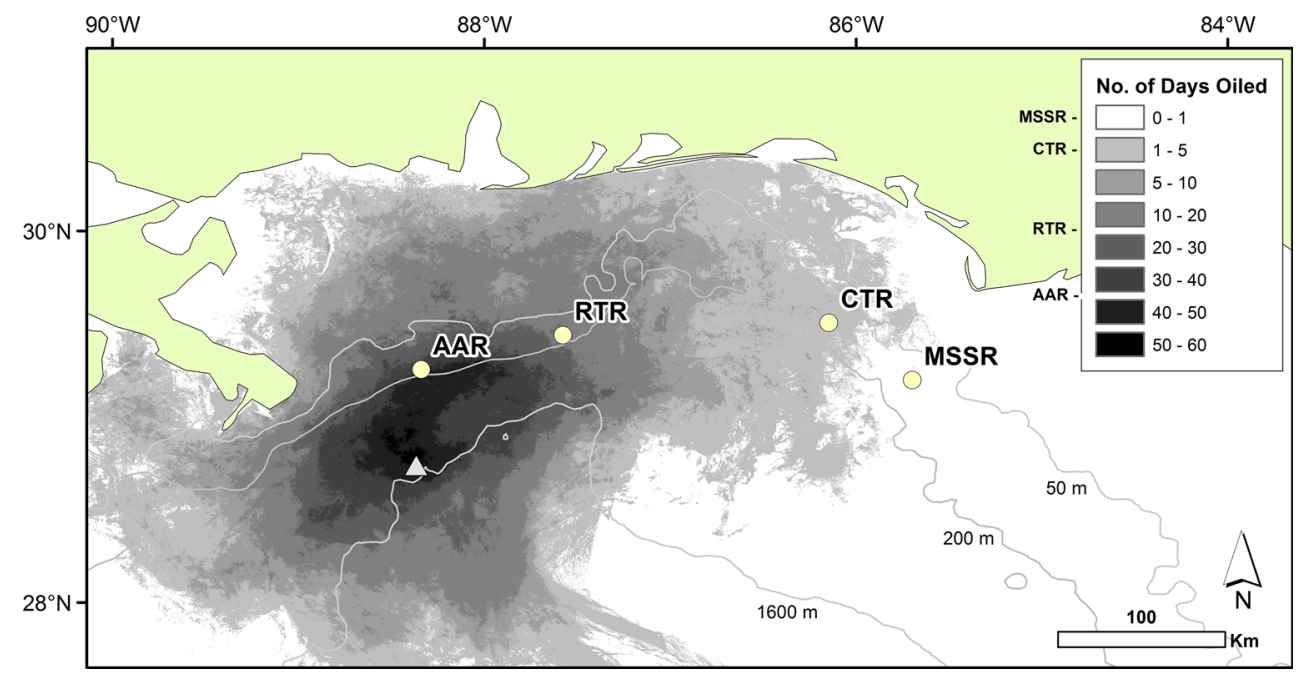


contaminated surface material toward the benthos (Passow et al. 2012) and/or re-suspension and advection of contaminated surface material in sediments from the reef perimeter onto the reef. These processes may have been intensified by storm events during the time when floating oil was present over the reef sites (Silva et al. 2015). Multiple studies have shown deleterious effects of oil and dispersant exposure on coral colonies and coral larvae (e.g., Loya and Rinkevich 1980; Goodbody-Gringley et al. 2013; DeLeo et al. 2015). Scleractinian coral tissue exposed to oil will break down (Johannes 1975), resulting in a thinning of coenosarc cell layers (Peters et al. 1981). The few studies that examined octocorals noted deleterious effects including polyp mortality and discoloration (DeLeo et al. 2015; Silva et al. 2015), inhibition of metamorphosis (Kushmora et al. 1997), and behavioral changes (Cohen et al. 1977).

Octocorals may be exposed to contaminants through the ingestion of contaminated plankton or suspended organic material. Octocorals ingest a wide variety of food resources, including zooplankton (Coma et al. 1994), detrital particulate organic matter (POM), nanoeukaryotes, ciliates (Ribes et al. 1999), and phytoplankton (Fabricius et al. 1995). Zooplankton can bio-accumulate toxic polycyclic aromatic hydrocarbons (Almeda et al. 2014) and exhibit isotopic field signatures that indicate oil-derived hydrocarbons have entered the food web (Graham et al. 2010). Effects of ingesting contaminated material by coral have not yet been studied.

Gorgonian octocoral colonies are good subjects of study to test for effects from the DWH spill because there is a precedent for injury to gorgonians from this oil spill (White et al. 2012; Silva et al. 2015). Furthermore, there is a potential for exposure to suspended and falling particles, and the reliance of these colonies on surface POM suggests a strong connection to surface plankton. This study asks: is there evidence of injury to gorgonian octocorals on mesophotic reefs near DWH? What types of injury were observed and to what degree? How does condition of gorgonians compare between sites near and far? Was there a change in condition to gorgonians before and after the DWH oil spill? We provide this information to assess potential injury to biota in the mesophotic zone relative to the DWH oil spill in the Gulf of Mexico.

\section{Methods}

\section{Field methods}

A before-after-control-impact (BACI) research design was used to study demersal fish and coral populations 50-100 m deep between Louisiana and West Florida at sites near and far from the Macondo well MC252 as part of the NRDA for DWH. BACI is a powerful research design that allows for detection of change over time. Two 'impact sites,' Alabama Alps Reef (AAR) and Roughtongue Reef/ Yellowtail Reef (RTR/YTR), were near the Macondo well within $109 \mathrm{~km}$ of the wellhead, 60-88 m below floating oil discharged during the DWH spill for $>19$ d, and were subject to dispersant applications (Fig. 1). In contrast, two other 'control' or 'reference sites' called Coral Trees Reef (CTR) and Madison Swanson South Reef (MSSR) were far from the Macondo well $(\sim 200 \mathrm{~km})$, below the surface slick for $<3 \mathrm{~d}$ or not at all, respectively, and were not subject to dispersant application. RTR and YTR were treated as one impact site because they are directly adjacent ( $\sim 1.5 \mathrm{~km}$ apart) with similar crest depths (Table 1).

The reefs were surveyed before the spill in 1989 (MAMES: Brooks 1991) and 1997-2003 (USGS: Weaver et al. 2002) and then after the spill, in 2010, 2011 and 2014 as part of the NRDA effort (Table 2). Remotely operated vehicles (ROVs) equipped with still and video cameras were used to conduct slow moving, low altitude, 2-5 min video transects on the reeftop biotope. The survey methods supported a BACI research design to compare condition and abundance of corals at mesophotic sites near and far from DWH, before and after the oil spill.

Table 1 Study site characteristics

\begin{tabular}{lcccccccccc}
\hline Reef & Lat & Long & $\begin{array}{l}\text { Distance } \\
(\mathrm{km})\end{array}$ & $\begin{array}{l}\text { Days } \\
\text { under } \\
\text { slick }\end{array}$ & $\begin{array}{l}\text { Area } \\
\left(\mathrm{km}^{2}\right)^{\mathrm{a}}\end{array}$ & $\begin{array}{l}\text { Reef base } \\
\text { depth }(\mathrm{m})\end{array}$ & $\begin{array}{l}\text { Reef crest } \\
\text { depth }(\mathrm{m})\end{array}$ & $\begin{array}{l}\text { Mean density } \\
\left(\text { corals } 100 \mathrm{~m}^{-2}\right)\end{array}$ & $\begin{array}{l}\text { Density } \\
\mathrm{SE}^{2}\end{array}$ & $\begin{array}{l}\text { Max. density } \\
\left(\mathrm{corals} 100 \mathrm{~m}^{-2}\right)\end{array}$ \\
\hline Alabama Alps & 29.255 & -88.339 & 57 & 39 & 0.126 & 88 & 72 & 21.1 & 2.1 & 47.7 \\
Roughtongue & 29.442 & -87.579 & 109 & 19 & 0.082 & 78 & 64 & 4.0 & 0.8 & 11.6 \\
Yellowtail & 29.440 & -87.575 & 109 & 19 & 0.038 & 68 & 60 & 17.0 & 2.8 & 35.9 \\
Coral Trees & 29.505 & -85.146 & 231 & 3 & 0.324 & 94 & 84 & 11.0 & 2.6 & 37.7 \\
Madison Swanson & 29.187 & -87.679 & 266 & 0 & 5.026 & 94 & 73 & 11.4 & 1.6 & 25.4 \\
\hline
\end{tabular}

Days under slick are from NOAA (2014) and distance $(\mathrm{km})$ refers to the distance in km from the Macondo well. Reef areas $\left({ }^{\mathrm{a}}\right)$ are from Nash and Randall (2015). Reef depths are from Weaver et al. (2002). Coral densities and standard errors (SE) are reported for target taxa in 2014, of the large sea fan group including Swiftia exserta, Hypnogorgia pendula, Thesea nivea, and Placogorgia spp 
Table 2 Cruise expeditions that contributed video for health assessment of corals

\begin{tabular}{|c|c|c|c|c|c|c|c|c|c|c|c|}
\hline \multirow[t]{2}{*}{ Cruise } & \multirow[t]{2}{*}{ Year } & \multirow[t]{2}{*}{ Month } & \multicolumn{5}{|c|}{ Reef survey sites } & \multirow[t]{2}{*}{ Transect time (min) } & \multicolumn{2}{|c|}{ Video frames } & \multirow[t]{2}{*}{ Analyses } \\
\hline & & & AAR & RTR & YTR & CTR & MSSR & & Total & Verified & \\
\hline \multicolumn{12}{|l|}{ Pre-spill } \\
\hline MAMES & 1989 & June & $X$ & & & & & 70.0 & 307 & 170 & I \\
\hline USGS & 1997 & August & & $X$ & & & & 43.9 & 109 & 48 & I \\
\hline USGS & 1999 & August & $X$ & & & & & 21.7 & 126 & 51 & I \\
\hline USGS & 2000 & March & & & $X$ & & & 7.6 & 25 & 12 & I \\
\hline USGS & 2001 & May & & & $X$ & & & 12.8 & 52 & 25 & I \\
\hline USGS & 2001 & August & & & & $X$ & $X$ & 44.6 & 367 & 166 & I \\
\hline USGS & 2002 & August & & & & $X$ & $X$ & 53.6 & 482 & 265 & I \\
\hline USGS & 2003 & June & & $X$ & $X$ & & & 41.4 & 182 & 109 & I \\
\hline Total & & & & & & & & 295.6 & 1650 & 846 & \\
\hline \multicolumn{12}{|l|}{ Post-spill } \\
\hline NRDA & 2010 & August & $\mathrm{X}$ & $X$ & & $X$ & & 62.5 & 263 & 90 & $\mathrm{C}$ \\
\hline NRDA & 2011 & September & $X$ & $X$ & $X$ & $X$ & $X$ & 340.3 & 1055 & 439 & $\mathrm{I}, \mathrm{M}, \mathrm{S}$ \\
\hline NRDA & 2014 & June-July & $X$ & $X$ & $X$ & $X$ & $X$ & 1448.0 & $2848^{\mathrm{a}}$ & NA & $\mathrm{M}, \mathrm{D}$ \\
\hline
\end{tabular}

Bold values represent total time and total number of video frames used in analyses

Cruises: MAMES Mississippi/Alabama Marine Ecosystem Survey, USGS United States Geological Survey, NRDA National Resource Damage Assessment. Reefs: AAR Alabama Alps, RTR Roughtongue, YTR Yellowtail, CTR Coral Trees, MSSR Madison Swanson South. Analyses: $I$ injury, $C$ chemistry, $M$ markers, $S$ species diversity, $D$ density

${ }^{a}$ Incomplete; full video review completed at impact sites only

Pre-spill video transect methods were comparable to post-spill methods, but standard definition cameras used pre-spill were generally lower resolution than high-definition cameras used after the spill. Full details on the ROVs and cameras are provided as Electronic Supplementary Materials (ESM-ROV Methods). Together the USGS, MAMES, and NRDA datasets comprised 295 min of prespill video to compare with 340 min of post-spill video in 2011. By combining these various datasets, a minimum of $30 \mathrm{~min}$ of high-quality transect video was available for each reef before and after DWH oil spill (ESM Fig. S1). While transect time differed among sites and time periods, total observations were comparable with large enough samples to facilitate robust statistical analyses based on proportions (see 'Statistical methods' section). Variable transect times were included as a continuous covariate in the statistical model with near and far sites run separately, thereby adjusting for any potential effect of effort.

All octocorals appearing along transects in 2011 were enumerated for analyses of species abundance and diversity. A group of select taxa were identified for assessment of health and condition based on discernible species and condition. Species that attain large colony sizes $(>20 \mathrm{~cm}$ in mean height or width) were readily identifiable in standard and high-definition video, and their condition could be assessed (Fig. 2). The species used in health analyses included Swiftia exserta, Hypnogorgia pendula, Thesea nivea, T. rubra, Placogorgia spp., Paramuricea spp., and
Muriceides cf. M. hirta. Paramuricea and Muriceides could not be distinguished from Placogorgia spp. in video and still images based on gross morphology, and were thus binned together for health analyses. Placogorgia were most common among the yellow plexaurid specimens collected, particularly $P$. rudis. A species identification guide to large gorgonian taxa is provided in ESM-Species guide. Small gorgonians (Nicella and Bebryce spp.) were difficult to discern in video due to image quality, colony size, and reproducibility of results, so these taxa were not assessed.

Due to differences in species composition among sites, the large, discernible gorgonian species were binned together into a single group (large gorgonians) for the BACI analysis. These were treated as one generic taxon in order to achieve comparable sample sizes among reef sites. This treatment rests on the assumption that the largest gorgonians at different sites have similar exposure to currents and similar feeding modes.

To monitor change in injury to gorgonians over time, weighted nylon rope markers flagged with syntactic foam and reflective tape were deployed at 12 locations in 2011. Deployments included six markers at AAR and six at RTR. Of these 12 markers, 11 were re-photographed in 2014. Gorgonian corals at each flagged location were photographed in 2011 with an AquaSLR digital still camera and then again in 2014 using a DPC-8800. The time-series images sought to reproduce ROV heading, camera angle, zoom, and lighting. 

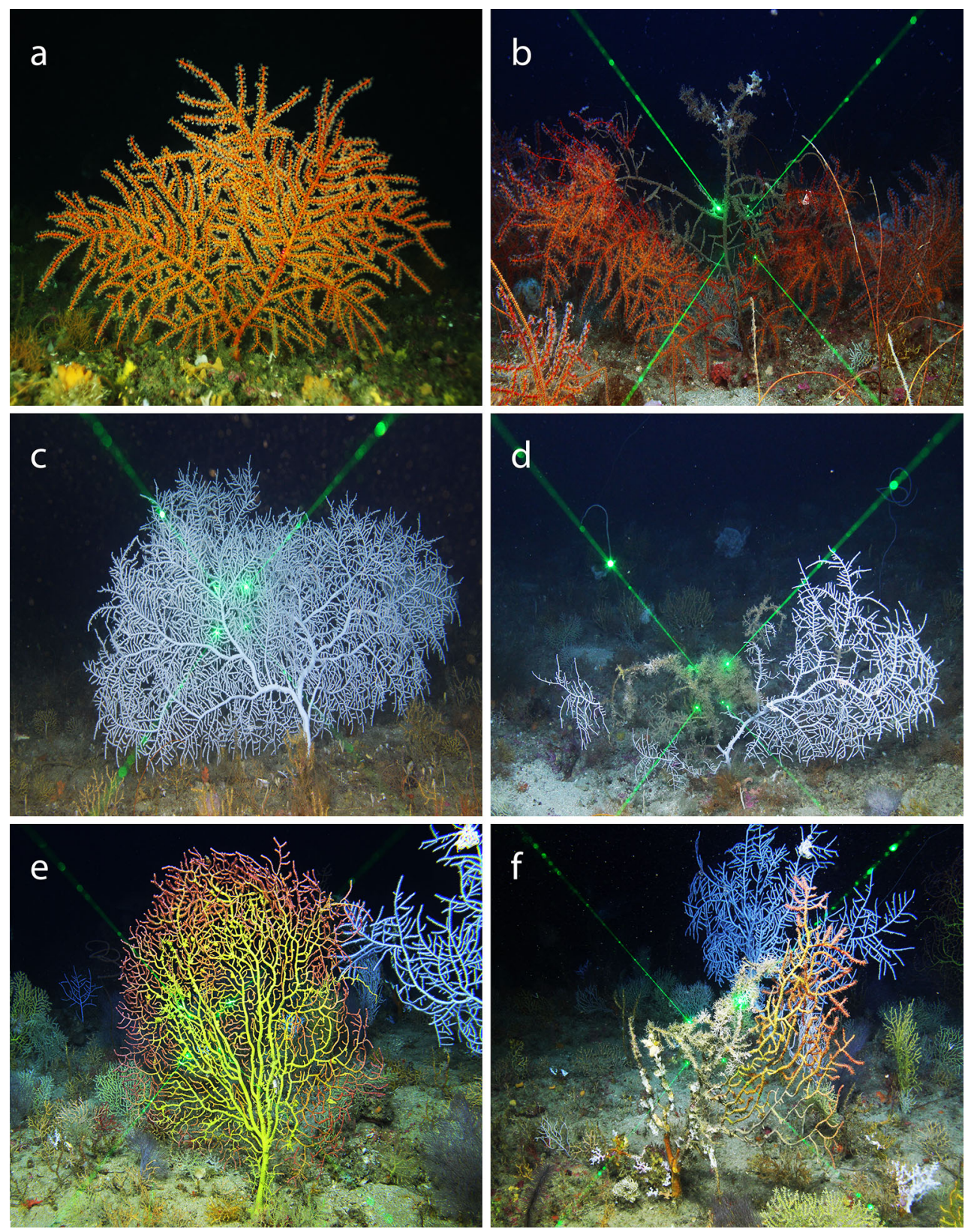

Fig. 2 Healthy and injured colonies of the gorgonian octocorals Swiftia exserta (a, b), Hypnogorgia pendula (c, d), and Placogorgia sp. (e, f) similar in appearance to Paramuricea

\section{Laboratory methods}

A total of 153 biological samples of octocorals were collected by ROV in $2010(n=31), 2011(n=58)$, and 2014 $(n=64)$ for the purposes of species identification and/or chemical analyses. Specimens were documented and preserved according to established protocols (Etnoyer et al. 2006). Morphological diagnosis was achieved by scanning electron microscopy (JEOL JSM5600LV) and light microscopy (Olympus SZX16). Genus-level determination was based upon the criteria set forth by Bayer (1981). Species-level identifications were made using the best available keys, and species identities were confirmed through consultation with experts at Smithsonian National Museum of Natural History (See ESM Figs. S4-S22).

For image-based analyses of in situ coral health and condition, target taxa were identified from video and a framegrab was generated for detailed assessment of health and condition. Health assessment was a three-stage process. Framegrabs were selected from each sequence so as to optimize resolution and visibility of the coral colonies being assessed. In the second review, gorgonians were 'verified,' i.e., assessed for discernible condition. Gorgonians were 'discernible' when the whole colony was clearly visible 
(e.g., cloudy water, fish, or colony orientation did not obscure large parts). In the third stage, injured and healthy regions on gorgonians were outlined using the software photoQuad (Trygonis and Sini 2012). Injury impact rankings (degree of injury) were assigned based on the categorical scale (0-4) described by White et al. (2012) where ' 0 ' denoted healthy and ' 4 ' indicated $>90 \%$ damage.

Injured colonies were categorized both in terms of their degree and type of injury. Types of injury included bare or denuded branches, broken branches, overgrowth, abnormal polyps, and/or severe discoloration. In the case of broken branches, the flabellum shape and condition were referenced to observed patterns of branching for the given taxa, and then breakage was coded at the holdfast, primary or secondary branch. Degree of injury was upweighted (increased by one level) when there was clear evidence of major branch loss.

\section{Statistical methods}

\section{Community composition}

The nonparametric analysis of similarity (ANOSIM) global R statistic (Clarke and Green 1988) was employed to test the null hypothesis of no difference in species composition among reef sites using non-metric multidimensional scaling techniques (nMDS) with an underlying Bray-Curtis similarity matrix based on counts of morphospecies along transects in 2011. Similarity percentages (SIMPER) were calculated using Bray-Curtis distance to identify the species groups contributing significantly to the differences among groups near and far from DWH. Multivariate analyses were conducted using the software PRIMER 6.1 (Clarke and Gorley 2006). Univariate analyses employed the nonparametric Kruskal-Wallis statistic with Tukey's honest significant difference (HSD) post hoc test to test the null hypothesis of no difference in frequency of occurrence for small and large gorgonians, fishing gear, and gear interactions.

\section{Health assessment}

The health assessment considered an ordered, categorical range of injuries by degree of intensity $(0-4$; White et al. 2012) in a BACI design. The categorical scale for injury was $0=$ healthy colony, $<1 \%$ injury; $1=1-10 \%$ injury; $2=10-50 \% ; 3=50-90 \%$; and $4=>90 \%$ (White et al. 2012). These ranks were used for consistency with other DWH-NRDA studies (White et al. 2012; Hsing et al. 2013; Fisher et al. 2014). The values were pooled together in two ways. Injury was considered in the binary sense, as absent $(0)$ or present $(1-4)$, and as low ranks $(0,1)$ or high ranks $(2,3,4)$. Dead gorgonian stolons and toppled colonies were treated in a separate class or injury rank $(=4)$ as appropriate. The marker study also used an ordered categorical response, in the form of $0=$ healthy, $1=$ injured, $2=$ more injured.

Severity of injury to large gorgonians was modeled as a function of proximity to Macondo well (near and far) and time (post-spill vs. pre-spill). Injury was treated as a binary response (logit, dependent variable) using logistic regression to obtain odds ratio estimates and Wald confidence intervals. The predictor variables were proximity and time frame, and the response variable was presence or absence of injury. Transect duration was included as a continuous covariate to adjust for variable transect lengths.

A sign test was used to measure the direction of change (from 2011 to 2014) in injured status for marked colonies revisited in 2014. The test statistic was calculated from the difference in injury (injury 2014-injury 2011) to evaluate the direction of change in status (more injured, less injured, or no change).

\section{Results}

\section{Community composition}

At least 31 octocoral species were collected (Table 3). Biological species richness ranged from nine species at CTR to 17 species at RTR. Morphospecies richness in video samples ranged from six at RTR to 11 at AAR. Species composition in video was significantly different among sites (ANOSIM test, Global $\mathrm{R}=0.66, p<0.01$ ) and among groups near and far from DWH (ANOSIM test, Global $\mathrm{R}=0.40, p<0.01$ ). Small gorgonian octocorals Bebryce spp., Nicella sp., and Villogorgia sp. contributed a cumulative $51.6 \%$ to the dissimilarity among distance groups, while large gorgonians $S$. exserta and Placogorgia spp. contributed an additional $18 \%$ to the dissimilarity among distance groups.

No single species occurred in equivalent abundance at all study sites. Small colonies $<20 \mathrm{~cm}$ (e.g., Bebryce and Nicella spp.) were highly abundant at some sites and relatively rare at others. The frequency of small fans was significantly different among sites (Kruskal-Wallis, $p<0.001)$. The frequencies of large gorgonians were more consistent among sites $(p=0.05$; ESM Fig. S2). Maximum densities of large gorgonians ranged from 12 to 48 colonies $100 \mathrm{~m}^{-2}$ (Table 1).

\section{Health assessment}

Was there a change in condition to gorgonian octocorals before and after the DWH oil spill?

There was a significant change in condition to gorgonian octocorals before and after the oil spill at sites below the 
Table 3 Octocoral species identified in sample collections 2010-2014

\begin{tabular}{|c|c|c|c|c|c|}
\hline \multirow[b]{2}{*}{ Species ID } & \multicolumn{3}{|c|}{ Northwest } & \multicolumn{2}{|c|}{ Northeast } \\
\hline & AAR & RTR & YTR & CTR & MSSR \\
\hline Bebryce cinerea & & $\mathrm{x}$ & & $\mathrm{x}$ & $\mathrm{x}$ \\
\hline Bebryce grandis & $\mathrm{x}$ & $\mathrm{x}$ & & & $\mathrm{x}$ \\
\hline Bebryce parastellata & $\mathrm{x}$ & $\mathrm{x}$ & & & $\mathrm{x}$ \\
\hline Carijoa riisei & & $\mathrm{x}$ & & & \\
\hline Ellisellidae sp.1 & & $\mathrm{x}$ & & & $\mathrm{x}$ \\
\hline Ellisellidae sp.2 & & $x$ & & & \\
\hline Ellisellidae sp.3 & & $\mathrm{x}$ & & & \\
\hline Hypnogorgia pendula & $\mathrm{x}$ & $\mathrm{x}$ & & $\mathrm{x}$ & $\mathrm{x}$ \\
\hline Leptogorgia sp. & $\mathrm{x}$ & $\mathrm{x}$ & $\mathrm{x}$ & & \\
\hline Muriceides $\mathrm{cf}$. M. hirta & $\mathrm{x}$ & & & & \\
\hline Nicella cf. $N$. americana & $\mathrm{x}$ & $\mathrm{x}$ & & & \\
\hline Nicella spp. & & $\mathrm{x}$ & & & $\mathrm{x}$ \\
\hline Paramuricea spp. & $\mathrm{x}$ & & & & $\mathrm{x}$ \\
\hline Placogorgia cf. P. mirabilis & & $\mathrm{x}$ & & & $\mathrm{x}$ \\
\hline Placogorgia tenuis & & & & $\mathrm{x}$ & \\
\hline Placogorgia rudis & $\mathrm{x}$ & & & & $\mathrm{x}$ \\
\hline Placogorgia sp.1 & $\mathrm{x}$ & $\mathrm{x}$ & & $\mathrm{x}$ & \\
\hline Placogorgia sp. 2 & $\mathrm{x}$ & & & $\mathrm{x}$ & $\mathrm{x}$ \\
\hline Scleracis cf. S. guadalupensis & & $\mathrm{x}$ & & & $\mathrm{x}$ \\
\hline Scleracis sp. & & $\mathrm{x}$ & & & $\mathrm{x}$ \\
\hline Swiftia exserta & $\mathrm{x}$ & $\mathrm{x}$ & $\mathrm{x}$ & & \\
\hline Thesea sp. & $\mathrm{x}$ & & & & \\
\hline Thesea cf. $T$. citrina & $\mathrm{x}$ & & & & \\
\hline Thesea cf. T. granulosa & $\mathrm{x}$ & & & & $\mathrm{x}$ \\
\hline Thesea $\mathrm{cf}$. $T$. guadalupensis & & & & $\mathrm{x}$ & \\
\hline Thesea $\mathrm{cf}$. T. hebes & & & & $\mathrm{x}$ & \\
\hline Thesea nivea & $\mathrm{x}$ & $\mathrm{x}$ & & & $\mathrm{x}$ \\
\hline Thesea cf. T. parviflora & & & & & $\mathrm{x}$ \\
\hline Thesea rubra & & & & $\mathrm{x}$ & $\mathrm{x}$ \\
\hline Villogorgia sp.1 & & $\mathrm{x}$ & $\mathrm{x}$ & $\mathrm{x}$ & $\mathrm{x}$ \\
\hline Villogorgia sp. 2 & & $\mathrm{x}$ & & & \\
\hline
\end{tabular}

Reefs are: Alabama Alps Reef (AAR), Roughtongue Reef (RTR), Yellowtail Reef (YTR), Coral Trees Reef (CTR), and Madison Swanson South Reef (MSSR). Species in the shaded rows were 'large taxa' included in health/injury analyses

surface oil slick ( $p<0.0001$, OR $=7.0-16.7$; Table 4). Odds of injury after the spill were 10.8 times higher than injury before the spill for all injury types (all ranks 1-4; Fig. 3a) and 6.9 times higher for injuries $>10 \%$ (ranks $\geq 2$; Fig. 3b). The historical injury rate for large gorgonians at impact sites was $4.3 \%(9 / 210)$ at RTR/YTR and $8.9 \%$ (24/271) at AAR, with all taxa pooled together (Fig. 4). Injury rates after the spill increased to $38 \%$ (35/93) and $50 \%(105 / 210)$ for RTR/YTR and AAR, respectively. Injury was documented across all taxa, ranging from $21 \%$ (5/24) of Placogorgia spp. to $62 \%$ (35/56) of Thesea spp. post-spill (Fig. 5).

Before the spill, the condition of gorgonians at sites AAR and RTR/YTR near DWH was healthy compared to far sites (Fig. 4). The odds of injured gorgonians far from the wellhead were historically $7.7(p<0.0001$, OR $=4.6-13.0)$ times higher than the odds of injured gorgonians near DWH. Pooling taxa at reference sites yield historical injury rates of $28.4 \%(92 / 324)$ and $10.8 \%$ (24/222), for Madison Swanson South Reef (MSSR) and Coral Trees (CTR), respectively. Pooling reference sites (CTR/MSSR) showed a moderate increase in gorgonian injury from $21 \%$ pre-spill to $26 \%$ post-spill. The change in condition at reference sites was not significantly different $(p=0.651, \mathrm{OR}=0.7-1.7)$ before and after the spill (Table 4, Fig. 3a, b).

Taken together, these results indicate a significant effect of time only at sites near the wellhead; gorgonian condition did not change significantly at sites far from the wellhead (Fig. 6). Before the spill, reference sites were degraded relative to impact sites, but after the spill the pattern reversed, with the odds of injured gorgonians near DWH $2.5(=1 / 0.4)$ times higher than far sites.

Several different statistical models were tested: an ordinal logistic regression model (OLRM) using all five ordered response (impact ranking) categories; a binary logistic regression model (LRM0) defining healthy versus injured as impact ranking 0 versus $(1,2,3,4)$ combined, and a binary logistic regression model (LRM1) defining healthy versus injured as impact rankings $(0,1)$ versus $(2$, $3,4)$ combined. Each of the various models gave the same interpretation and similar odds ratio (OR). The binary logistic regression model was presented, due to concerns about low cell frequencies for some of the impact ranking categories. Goodness-of-fit tests suggested some degree of lack of model fit, although receiver operating characteristic (ROC) curves indicate reasonably good predictive power for sites near the wellhead (area under the ROC curve ranged from 0.74 to 0.78 ).

\section{What types of injury were observed and to what degree?}

Types of injury to large gorgonians were similar among sites near and far, both pre-spill and post-spill. While most injured gorgonian colonies exhibited more than one form of injury, the most common primary forms of injury across all sites post-spill were overgrowth (47\%), broken branches $(12 \%)$, or bare branches $(10 \%)$. Frequency of primary injury types across all sites was similar pre-spill, with examples of overgrowth (49\%), broken branches (26\%), and bare branches (14\%). Overgrowth consisted primarily of hydroids or sedimented material. Bare branches had clear loss of the coenosarc and polyps, with only the axis remaining. Post-spill, overgrowth was also the predominant form of injury at sites both near $(48 \%)$ and far $(45 \%)$. Less common forms of injury included severe discoloration, eroded polyps, and toppled colonies. Severe discoloration was unusually dark tissue of brown or gray ( $S$. exserta, H. pendula and Placogorgia spp.) or unusually light tissue with erosion of polyps (T. nivea).

\section{Was there a change in condition to marked colonies after the DWH oil spill?}

Colonies at the marked locations included six Hypnogorgia and 12 Swiftia. Of the 18 total marked colonies, eight were 
Table 4 Summary statistics showing results of logistic regression models

\begin{tabular}{lllllll}
\hline Effect & Sites & $d f$ & $p$ & Odds ratio ${ }^{a}$ (and 95 \% CL) & Model & Area under ROC curve \\
\hline Time frame (post vs. pre) & Near & 1 & $<0.0001$ & $10.8(7.0-16.7)$ & LRM0 & 0.78 \\
& & 1 & $<0.0001$ & $6.9(4.4-10.7)$ & LRM1 & 0.74 \\
& & 1 & $<0.0001$ & $10.0(6.5-15.4)$ & OLRM & N/A \\
& Far & 1 & 0.651 & $1.1(0.7-1.7)$ & LRM0 & 0.58 \\
& & 1 & 0.360 & $1.2(0.8-2.0)$ & LRM1 & 0.60 \\
& & 1 & 0.491 & $1.2(0.8-1.8)$ & OLRM & N/A \\
Proximity (far vs. near) & Pre & 1 & $<0.0001$ & $7.7(4.6-13.0)$ & LRM0 & 0.70 \\
& & 1 & $<0.0001$ & $5.8(3.3-9.9)$ & LRM1 & 0.68 \\
& & 1 & $<0.0001$ & $7.2(4.3-12.0)$ & OLRM & N/A \\
& Post & 1 & $<0.0001$ & $0.4(0.3-0.6)$ & LRM0 & 0.60 \\
& & 1 & 0.0057 & $0.5(0.3-0.8)$ & LRM1 & 0.57 \\
\hline
\end{tabular}

LRM0 is a logistic regression model (binary response) with healthy defined as impact ranking $=0$, and injured defined as impact ranking $=(1$, 2,3 , or 4). LRM1 is a logistic regression model (binary response) with healthy defined as impact ranking $=0$ or 1 , injured defined as impact ranking $=(2,3$, or 4$)$. OLRM is an ordinal logistic regression model using five ordered response categories (impact rankings $0,1,2,3,4)$

${ }^{a}$ Odds of injured coral

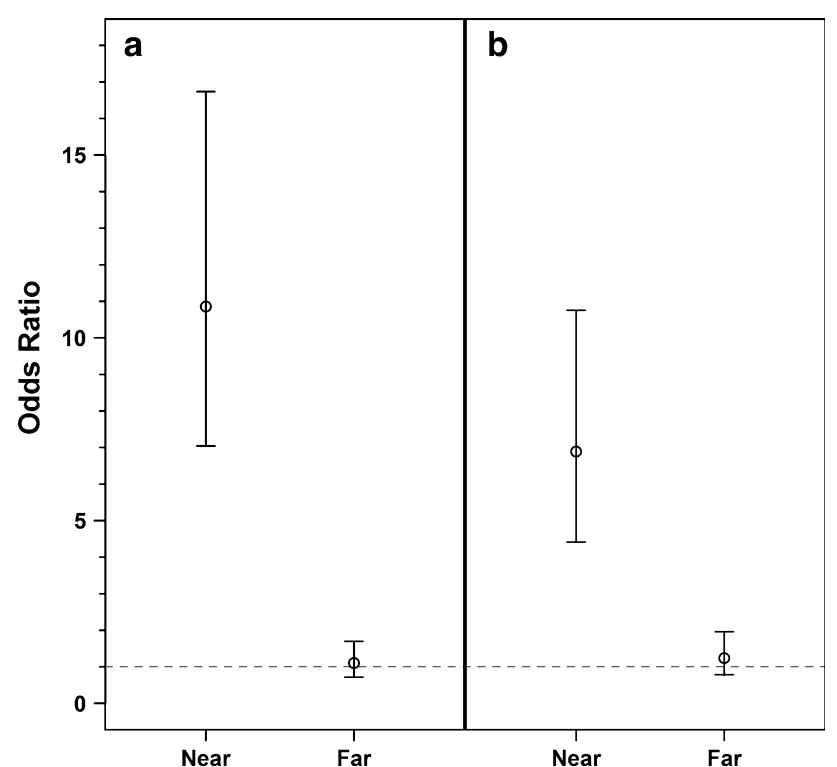

Fig. 3 Odds ratio estimates (circles) with $95 \%$ confidence intervals (error bars) for odds of injury post-spill versus odds of injury prespill at sites near and far from Macondo wellhead. a Odds ratios with rank $0=$ healthy, and ranks $1-4=$ injury. b Odds ratios with ranks 0 , $1=$ healthy; and ranks $2-4=$ injury. The dashed line at $y=1$ indicates no significant difference from pre-spill

considered healthy and ten injured in 2011. Marked corals imaged in both 2011 and $2014(n=18)$ indicated that most healthy corals remained healthy $(7 / 8=88 \%)$ and most colonies that were injured in 2011 progressed in injury (8/ $10=80 \%)$. The null hypothesis of no change was rejected $(p<0.01$, two-sided sign test), and the test statistic was positive, indicating a direction of change from less injured to more injured. Injuries included loss of tissue, expanded overgrowth, pruning of branches, and toppling of the colony. One injured colony of Swiftia remained at the same level of injury. In the only case where a colony progressed from injured to healthy, injury in 2011 was to $4 \%$ of the Swiftia colony in overgrowth on secondary branches. The location of initial injury appeared to have some influence on the rate of injury progression. For example, injury of $<3 \%$ at the base of a Hypnogorgia colony resulted in rapid progression of overgrowth, loss of branches, and collapse of the colony. Thus, low percentages of injury (3-4\%) could be followed subsequently by either colony recovery or colony collapse (Fig. 7).

\section{Discussion}

This study found clear evidence of injury to at least four species of gorgonian octocorals on mesophotic reefs situated below the surface oil slick from the Deepwater Horizon blowout at Macondo wellhead. Results indicate a highly significant decline in condition at sites nearest the wellhead after the spill. Decline in condition was severe, from $<10 \%$ of colonies injured before 2003 to more than $50 \%$ of colonies injured in 2011. Nearly all injured colonies marked in 2011 declined in condition, suggesting that recovery of corals is unlikely. The majority of healthy colonies marked in 2011 remained healthy, suggesting that the cause of injury was ephemeral. Injury occurred in all taxa of large gorgonians, including $S$. exserta, H. pendula, Thesea spp., and Placogorgia spp., in the form of eroded polyps, discoloration, bare branches, overgrowth, missing branches, and broken branches. 
Fig. 4 Overall frequency of injury to large gorgonians, with all ranks (1-4) combined, before and after Deepwater Horizon oil spill at the Macondo well
Fig. 5 Frequency of injury post-spill for four large sea fan taxa (Thesea spp., Swiftia exserta, Hypnogorgia pendula, and Placogorgia spp.) occurring on northwest Gulf of Mexico mesophotic reefs. Asterisks indicate taxa were absent on the transects
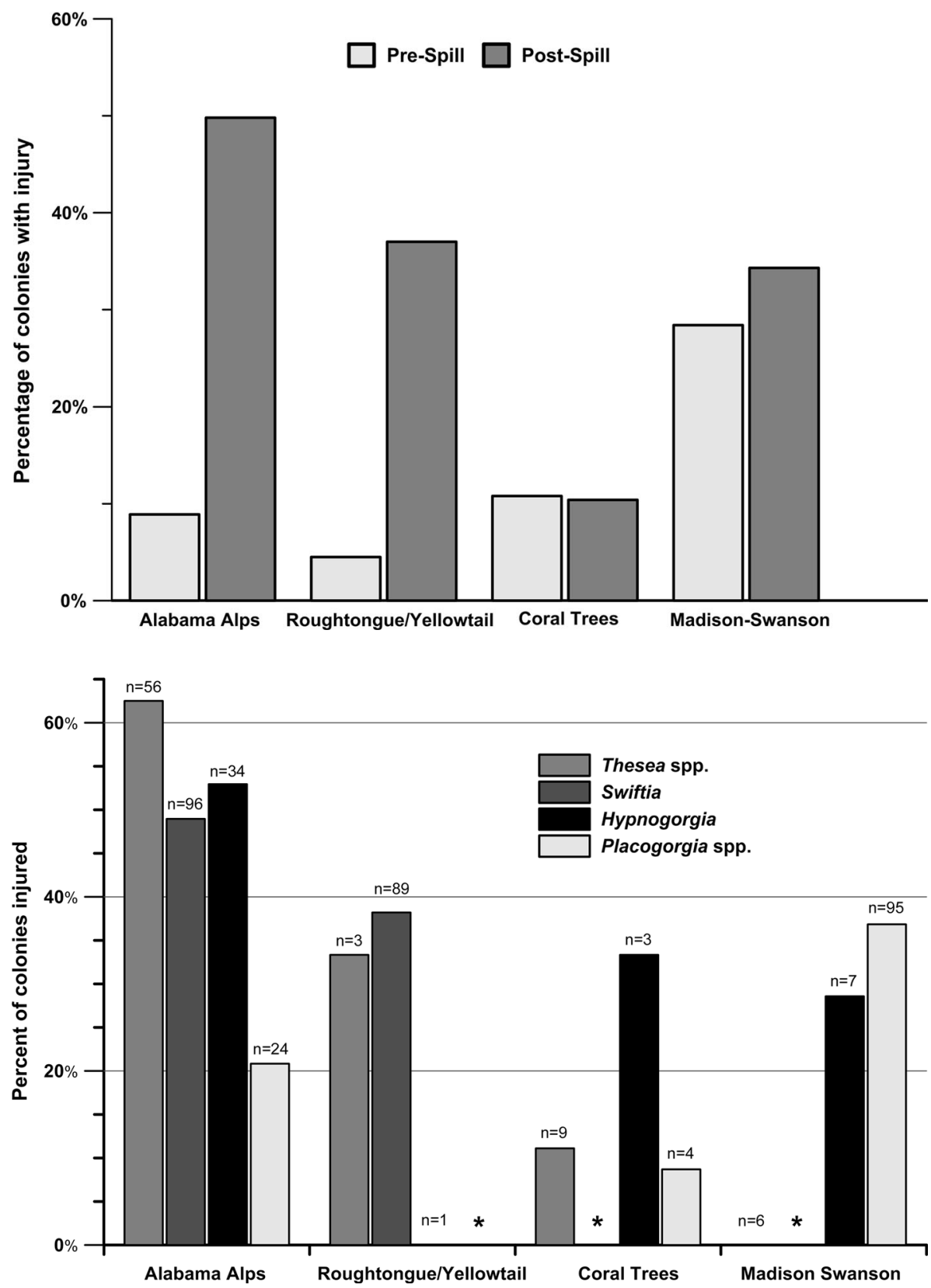

The findings are consistent with the results of other studies showing benthic impacts to deep-sea corals from the Deepwater Horizon oil spill (White et al. 2012; Hsing et al. 2013; Fisher et al. 2014; Silva et al. 2015). Injuries to Paramuricea gorgonians were linked to oil from the Macondo well by White et al. (2012). Those results were later extended to other sites up to $22 \mathrm{~km}$ from the wellhead (Fisher et al. 2014). These studies reported a patchy distribution of injury (i.e., not mass mortality) with healthy and injured colonies co-occurring, much like the observations presented here. A decline in condition of marked injured gorgonians $(n=19)$ was also reported near $1500 \mathrm{~m}$ depth (Hsing et al. 2013). This temporal decline is consistent with marker observations $(n=18)$ in the mesophotic zone. These studies near Macondo wellhead were able to produce evidence linking the DWH spill by 'fingerprinting' oiled sediments recovered from the branches and polyps of gorgonians (White et al. 2012).

One key difference between this and other studies of deep-sea corals (White et al. 2012; Fisher et al. 2014) is that this is the first to employ a BACI design. The context gained through this approach was demonstrable evidence of pre-spill injury to gorgonians at reference sites far from the wellhead, nearly $200 \mathrm{~km}$ away. It is unlikely injuries at reference sites can be attributed to DWH because injuries to large gorgonians were apparent in the earliest ROV 
Fig. 6 Frequency of

observation for each degree of injury $(0=<1 \%$,

$1=1-10 \%, 2=10-50 \%$,

$3=50-90 \%, 4=>90 \%$ ) for

large gorgonians on study sites

near and far from Macondo

well, before and after the

Deepwater Horizon spill
Near

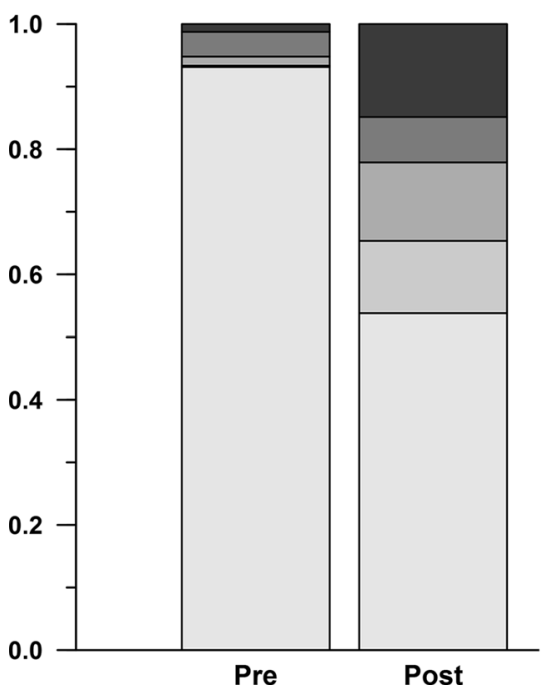

Far

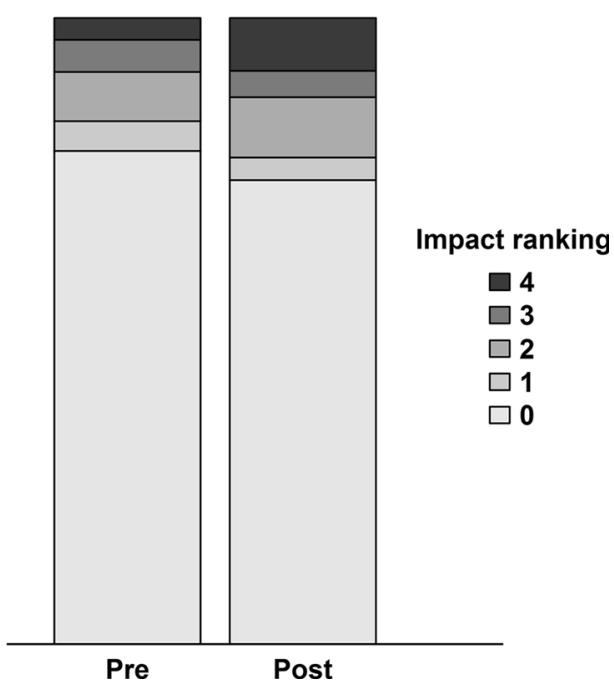

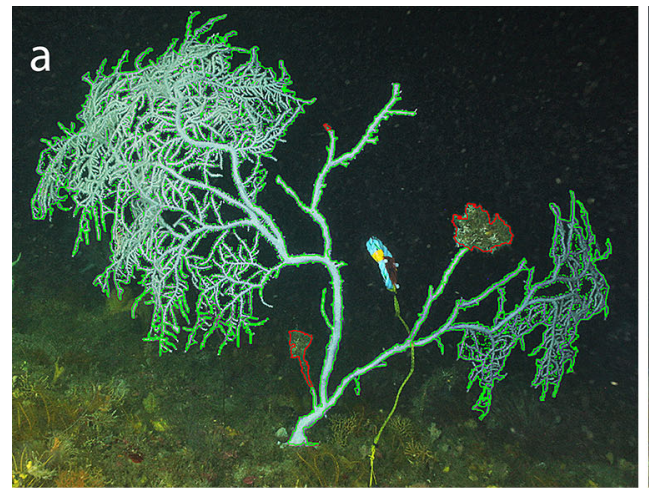
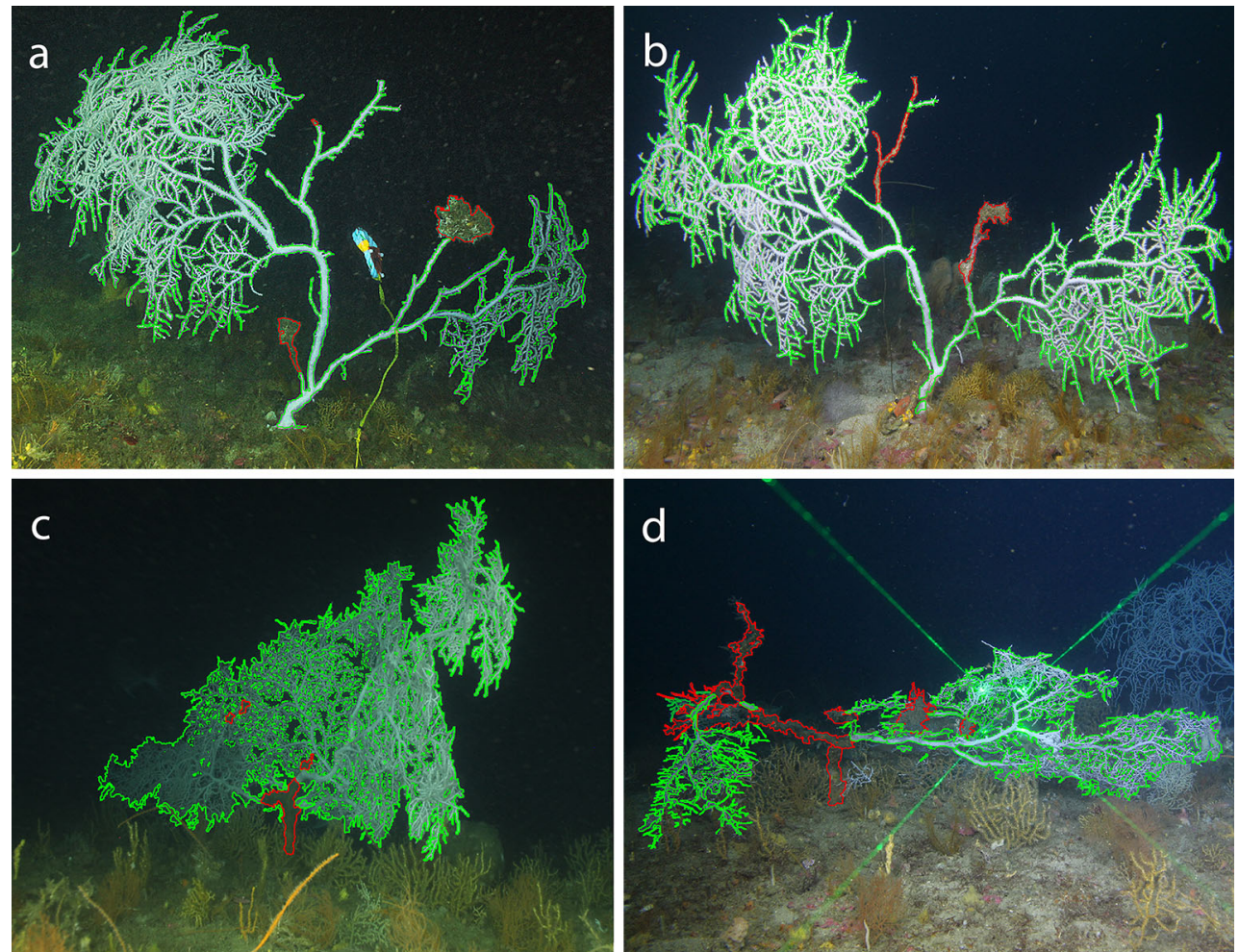

Fig. 7 Two colonies of Hypnogorgia pendula marked in 2011 (a, c) and revisited in 2014 (b, d). Green outlines indicate healthy sections, and red outlines indicate injured sections

surveys of the reefs available to the study in 1997. Additionally, condition of colonies was unchanged pre- and post-spill, in contrast to the dramatic changes observed at reefs near Macondo well. Reference sites were under surface slicks for $<3 \mathrm{~d}$ or not at all.

The most probable cause of injury to corals on reference sites was bottom-contact fishing. Bottom-contact fishing is a known stressor to deep-sea coral habitats and the likely source of pre-spill injury at reference sites. Bottom longlines in particular are recognized as a threat to gorgonian octocorals (Sampaio et al. 2012). Monofilament line occurred in and around gorgonian colonies, with significantly more line and more interactions observed at reference sites (Kruskal-Wallis, $p<0.01$; ESM Fig. S3). 
Coral Trees Reef and Madison Swanson South Reef are both situated in a region known as the 'northern grounds' for the Gulf of Mexico bottom longline fishery. The northern grounds are "the area of the Gulf where fishing actually began in the 1800's" (Prytherch 1983). Intense fishing pressure at MSSR led to closure in 2000, when the Fishery Management Council put all bottom-contact gear off limits. Low levels of bottom longline fishing effort were reported from the Pinnacles region in 2001, but the vast majority of effort was concentrated in the eastern Gulf, near Tampa, Florida (Scott-Denton et al. 2011). Observations of fishing line on transects at Pinnacle Trend sites were few. Impact sites are not likely to have incurred higher levels of injury from fishing than reference sites in a relatively brief time frame.

Octocorals are subject to a wide variety of natural and anthropogenic stressors beyond fisheries. Known stressors to octocorals include disease, ocean warming, predation by corallivores, toppling by hurricanes, and sedimentation. These alternatives are recognized here as counterpoint explanations for potential causes of injury unrelated to the Deepwater Horizon incident.

While fungal infections have been shown to eradicate gorgonian populations in tropical waters (Kim and Harvell 2004), few diseases have been reported for deep-water octocorals. Disease has not been reported from Gulf mesophotic taxa to our knowledge. Furthermore, disease outbreaks are typically reported to occur in one or a few host taxa (e.g., Gorgonia ventalina, Eunicella verrucosa; Hall-Spencer et al. 2007) and are not ubiquitous to a reef. The indiscriminate nature of the observed injuries suggests that disease is not the cause of injury at impact sites.

Octocorals are susceptible to surface warming in shallow waters (Sánchez et al. 2014), but there is presently no evidence of warming-related injury to octocorals in deep water. A dramatic warming event occurred in 2005 that caused bleaching to 40-60\% of shallow water corals at Flower Garden Banks in the western Gulf of Mexico, but no observations were deeper than $30 \mathrm{~m}$ and no mortality was evident (Eakin et al. 2010). Maps of temperature anomalies indicate impact sites were minimally affected. The reduced severity of the anomalies and depth of the mesophotic reefs suggest that surface warming is not the cause.

Corallivore predators can occur in deep water (Mah et al. 2010), but they do not explain the injuries observed in the Gulf of Mexico. Predators of gorgonian octocorals include asteroid sea stars, flamingo tongue snails, gastropods, and cidaroid urchins, among others. However, there were no obvious infestations of any of these predators in pre- or post-spill video. The frequency of occurrence for predators was very low among sites, with no obvious examples of predator-inflicted injury.
Hurricanes and storms can impact shallow coral reefs in the Caribbean, and topple gorgonian octocoral colonies attached to poorly consolidated substrate. Multiple hurricanes have passed over the Pinnacles sites in the past few decades, but the reef depths should provide an insulating effect from surface winds. Hurricanes Ivan and Katrina both passed near to the Pinnacles sites as strong Category 4 storms, in 2004 and 2005, respectively, yet other storms of similar strength (Andrew in 1992 and Opal in 1995) occurred prior to the pre-spill surveys, and the effects of those storms were not apparent in pre-spill surveys. It is not likely that hurricanes were the cause of injury observed in 2011, as prior hurricanes were not associated with subsequent damage to the mesophotic reefs.

Other studies have invoked DWH as the causative agent for declines in the mesophotic zone, including lesions observed in deep-water crabs (Felder et al. 2014) and fishes (Murawski et al. 2014) and up to $50 \%$ injury to a broad range of corals on Pinnacle Trend reefs (Silva et al. 2015). The latter analysis included black corals and sea whips and used a different dataset of high-resolution still images from another set of pre-spill surveys, reaching the same conclusions presented here.

Unlike other studies documenting DWH impacts to deep-sea corals (White et al. 2012; Fisher et al. 2014), the current study of mesophotic corals at sites 50-100 km from DWH did not include fingerprinting of 'Macondo 252' oil on injured octocorals nor in sediments, but some chemical analyses were conducted. Total polycyclic aromatic hydrocarbons (PAHs) in tissues of corals on Pinnacle Trend reefs were observed in 2010 at low levels (Silva et al. 2015). Cooksey et al. (2014) also reported total PAHs in shelf sediments after the spill (August 2010) at very low levels, below sediment quality bio-effect guidelines developed with data for estuarine species. However, the low levels of PAHs observed near Pinnacle Trend were slightly higher compared to eastern sites with sandy sediments. There are no well-established bio-effect levels for offshore sediments (Cooksey et al. 2014), nor deep-water octocorals, so it may be possible that bio-effect thresholds for estuarine invertebrates are higher than thresholds for deep-water species. Furthermore, dispersants may have also played a role in the development of injury (DeLeo et al. 2015).

The lack of accumulation of DWH-related hydrocarbons in nearby shelf sediments does not preclude the possibility of DWH-related impacts to mesophotic corals located in these same areas. It is likely that oil and dispersant particles would have been patchily distributed in the water column this far from the wellhead (Valentine et al. 2014). Therefore, oil contaminants would be unlikely to accumulate in large quantities on the sediment surface, but suspended material could still cause harm to suspension feeders as it came into contact with upright corals. 
In the absence of compelling evidence attributable to other known potential sources of injury, the oil slick from Deepwater Horizon remains the likely causative agent for injury observed on mesophotic reefs in the Pinnacle Trend. The persistence and proximity of the surface slick and dispersant applications, as well as evidence of oil-contaminated marine snow (Passow et al. 2012) and seafloor deposition of surface-derived carbon (Chanton et al. 2014) all suggest a pathway for contaminants to reach the mesophotic reefs. Contact of surface slick-derived oil or dispersants with mesophotic octocorals may have occurred directly with sinking of oil or oil-contaminated material, or indirectly, through ingestion of contaminated plankton or suspended organic material.

In conclusion, there is clear evidence of injury and decline to gorgonian octocorals at sites that were situated below the surface slick in the spring of 2010. The degree of injury is substantial, with up to $50 \%$ of sea fans affected; the time frame suggests that the Macondo blowout was a likely causative agent of the decline. Other potential sources of injury, including fisheries, hurricanes, water temperature, and predators, were included in analyses, but do not appear to account for changes to octocoral health at sites in the Pinnacle Trend.

Alabama Alps Reef, Roughtongue Reef, and Yellowtail Reef were selected as representative sites in this study, but are only a few of many reefs known to harbor octocorals and abundant fishes in the Pinnacle Trend. Recent GISderived areas of potential reef habitat indicate that the study sites evaluated may encompass $<3 \%$ of total mesophotic reef area in the mapped area below the slick (Nash and Randall 2015). The results presented here may vastly underestimate the extent of impacts to mesophotic reefs in the northern Gulf of Mexico.

This study identifies multiple potential sources of injury to gorgonian octocorals of the Gulf of Mexico mesophotic reefs, both within and outside the scope of the Deepwater Horizon oil spill. Monitoring to date suggests recovery to injured colonies is unlikely. Nevertheless, a number of healthy colonies still remain on these reefs, and data suggest that healthy colonies will remain so in the absence of new stressors. Habitat protection and habitat restoration efforts are recommended to ameliorate collateral damage from fishing and to accelerate the recovery rates to gorgonian aggregations in the northern Gulf of Mexico; deepwater monitoring programs should be established to document the progress and effect of the new conservation measures.

Acknowledgments The authors would like to acknowledge support from the DWH NRDA since 2010. We would also like to acknowledge the efforts of USGS since 1997 under the leadership of Dr. Ken Sulak. The captain and crews of NOAA ship Nancy Foster, RV Holiday Chouest, and RV Walton Smith were indispensable, as were the efforts of ROV teams from Deep Sea Systems International and Schilling Robotics. We appreciate A. Shuler, M. Rittinghouse, E. Couch, J. Frometa, and G. Hanna for their significant contributions. A. Shuler prepared the species identification guide in ESM. Special thanks to SD Cairns for help with species identification.

\section{Compliance with ethical standards}

NOAA Disclaimer This publication does not constitute an endorsement of any commercial product or intend to be an opinion beyond scientific or other results obtained by the National Oceanic and Atmospheric Administration (NOAA). No reference shall be made to NOAA, or this publication furnished by NOAA, to any advertising or sales promotion which would indicate or imply that NOAA recommends or endorses any proprietary product mentioned herein, or which has as its purpose an interest to cause the advertised product to be used or purchased because of this publication.

Open Access This article is distributed under the terms of the Creative Commons Attribution 4.0 International License (http://crea tivecommons.org/licenses/by/4.0/), which permits unrestricted use, distribution, and reproduction in any medium, provided you give appropriate credit to the original author(s) and the source, provide a link to the Creative Commons license, and indicate if changes were made.

\section{References}

Almeda R, Baca S, Hyatt C, Buskey EJ (2014) Ingestion and sublethal effects of physically and chemically dispersed crude oil on marine planktonic copepods. Ecotoxicology 23:988-1003

Bayer FM (1961) The shallow-water Octocorallia of the West Indian region: a manual for marine biologists. Martinus Nijhoff, The Hague

Bayer FM (1981) Key to the genera of Octocorallia exclusive of Pennatulacea (Coelenterata: Anthozoa), with diagnoses of new taxa. Proc Biol Soc Wash 94:902-947

Brooks JM (ed) (1991) Mississippi-Alabama continental shelf ecosystem study: data summary and synthesis. OCS Study MMS 91-0062. U.S. Department of the Interior, Minerals Management Service, Gulf of Mexico OCS Regional Office, New Orleans

Buhl-Mortensen L, Mortensen PB (2005) Distribution and diversity of species associated with deep-sea gorgonian corals off Atlantic Canada. In: Freiwald A, Roberts JM (eds) Cold-water corals and ecosystems. Springer, Heidelberg, pp 849-879

Cairns SD, Bayer FM (2009) Octocorallia (Cnidaria) of the Gulf of Mexico. In: Felder DL, Camp DK (eds) Gulf of Mexico-origins, waters, and biota, vol 1., BiodiversityTexas A\&M Press, College Station, pp 321-331

Chanton J, Zhao T, Rosenheim BE, Joye S, Bosman S, Brunner C, Yeager KM, Diercks AR, Hollander D (2014) Using natural abundance radiocarbon to trace the flux of petrocarbon to the seafloor following the Deepwater Horizon oil spill. Environ Sci Technol 49:847-854

Clarke KR, Green RH (1988) Statistical design and analysis for a 'biological effects' study. Mar Ecol Prog Ser 46:213-226

Clarke KR, Gorley RN (2006) PRIMER v6: user manual/tutorial. PRIMER-E, Plymouth

Cohen Y, Nissenbaum A, Eisler R (1977) Effects of Iranian crude oil on the Red Sea octocoral Heteroxenia fuscescens. Environ Pollut 12:173-186 
Coma R, Gili JM, Zabala M, Riera T (1994) Feeding and prey capture cycles in the aposymbiontic gorgonian Paramuricea clavata. Mar Ecol Prog Ser 115:257-270

Cooksey C, Hyland J, Fulton M, Balthis L, Wirth E, Wade T (2014) Ecological condition of coastal waters along the U.S. Continental Shelf of the Northeastern Gulf of Mexico: 2010. NOAA Technical Memorandum NOS NCCOS 188. NOAA National Ocean Service, Charleston

Davies AJ, Duineveld GC, Lavaleye MS, Bergman MJ, van Haren H, Roberts JM (2009) Downwelling and deep-water bottom currents as food supply mechanisms to the cold-water coral Lophelia pertusa (Scleractinia) at the Mingulay Reef complex. Limnol Oceanogr 54:620-629

DeLeo DM, Ruiz-Ramos DV, Baums IB, Cordes EE (2015) Response of deep-water corals to oil and chemical dispersant exposure. Deep Sea Res Part II Top Stud Oceanogr. doi:10.1016/j.dsr2.2015.02.028

Eakin CM, Morgan JA, Heron SF, Smith TB, Liu G, Alvarez- Filip L, Baca B, Bartels E, Bastidas C, Bouchon C, Brandt M, Bruckner AW, Bunkley-Williams L, Cameron A, Causey B, Chiappone M, Christensen TRL, Crabbe MJC, Day O, de la Guardia E, DíazPulido G, DiResta D, Gil-Agudelo D, Gilliam DS, Ginsburg RN, Gore S, Guzmán HM, Hendee JC, Hernández-Delgado EA, Husain E, Jeffrey CFG, Jones RJ, Jordán-Dahlgren E, Kaufman LS, Kline DI, Kramer PA, Lang JC, Lirman D, Mallela J, Manfrino C, Maréchal JP, Marks K, Mihaly J, Miller WJ, Mueller EM, Orozco Toro CA, Oxenford HA, Ponce-Taylor D, Quinn N, Ritchie KB, Rodríguez S, Rodríguez Ramírez A, Romano S, Samhouri JF, Sánchez JA, Schmahl GP, Shank BV, Skirving WJ, Steiner SCC, Villamizar E, Walsh SM, Walter C, Weil E, Williams EH, Woody Roberson K, Yusuf Y (2010) Caribbean corals in crisis: record thermal stress, bleaching, and mortality in 2005. PLoS One 5(11):e13969

Etnoyer P, Cairns SD, Sanchez JA, Reed JK, Lopez JV, Schroeder WW, Brooke SD, Watling L, Baco-Taylor A, Williams GC, Lindner A, France SC, Bruckner AW (2006) Deep-sea coral collection protocols. NOAA Technical Memorandum NMFSOPR-28, Silver Spring

Fabricius KE, Genin A, Benayahu Y (1995) Flow-dependent herbivory and growth in zooxanthellae-free soft corals. Limnol Oceanogr 40:1290-1301

Felder DL, Thoma BP, Schmidt WE, Sauvage T, Self-Krayesky SL, Chistoserdov A, Bracken-Grissom HD, Fredericq S (2014) Seaweeds and decapod crustaceans on Gulf deep banks after the Macondo oil spill. BioScience 64:808-819

Fisher CR, Demopoulos AWJ, Cordes EE, Baums IB, White HK, Bourque JR (2014) Coral communities as indicators of ecosystem-level impacts of the deepwater horizon spill. Bioscience 64:796-807

Gardner JV, Sulak KJ, Dartnell P, Hellequin L, Calder B, Mayer LA (2000) Cruise report RV Ocean Surveyor Cruise O-1-00-GM the bathymetry and acoustic backscatter of the Pinnacles Area, Northern Gulf of Mexico May 23, through June 10, 2000. Venice, LA to Venice, LA. U.S. Geological Survey Open-File Report 00-350

Gittings SR, Bright TJ, Schroeder WW, Sager WW, Laswell SJ, Rezak R (1992) Invertebrate assemblages and ecological controls on topographic features in the Northeast Gulf of Mexico. Bull Mar Sci 50:435-455

Goodbody-Gringley G, Wetzel DL, Gillon D, Pulster E, Miller A, Ritchie KB (2013) Toxicity of deepwater horizon source oil and the chemical dispersant, Corexit ${ }^{\circledR} 9500$, to coral larvae. PLoS One 8:e45574

Graham WM, Condon RH, Carmichael RH, D'Ambra I, Patterson HK, Linn LJ, Hernandez FJ Jr (2010) Oil carbon entered the coastal planktonic food web during the Deepwater Horizon oil spill. Environ Res Lett 5:e45301
Hall-Spencer JM, Pike J, Munn CB (2007) Diseases affect cold-water corals too: Eunicella verrucosa (Cnidaria: Gorgonacea) necrosis in SW England. Dis Aquat Org 76:87-97

Hsing P-Y, Fu B, Larcom EA, Berlet SP, Shank TM, Govindarajan AF, Lukasiewicz AJ, Dixon PM, Fisher CR (2013) Evidence of lasting impact of the Deepwater Horizon oil spill on a deep Gulf of Mexico coral community. Elem Sci Anthr 1:0000012

Johannes RE (1975) Pollution and degradation of coral reef communities. In: Johannes RE, Ferguson Wood EJ (eds) Tropical marine pollution. Elsevier, Amsterdam, pp 13-51

Kahng SE, Garcia-Sais JR, Spalding HL, Brokovich E, Wagner D, Weil E, Hinderstein L, Toonen RJ (2010) Community ecology of mesophotic coral reef systems. Coral Reefs 29:255-275

Kim K, Harvell D (2004) The rise and fall of a six year coral fungal epizootic. Am Nat 164(S5):S52-S63

Krieger KJ, Wing BL (2002) Megafauna associations with deepwater corals (Primnoa spp.) in the Gulf of Alaska. Hydrobiologia 471:83-90

Kushmora A, Henning G, Hofmann DK, Benayahu Y (1997) Metamorphosis of Heteroxenia fuscescens planulae (Cnidaria: Octocorallia) is inhibited by crude oil: a novel short term toxicity bioassay. Mar Environ Res 43:295-302

Loya YM, Rinkevich B (1980) Effects of oil pollution on coral reef communities. Mar Ecol Prog Ser 3:167-180

Mah C, Nizinski M, Lundsten L (2010) Phylogenetic revision of the Hippasterinae (Goniasteridae; Asteroidea): systematics of deep sea corallivores, including one new genus and three new species. Zool J Linn Soc 160:266-301

McNutt MK, Camilli R, Crone TJ, Guthrie GD, Hsieh PA, Ryerson TB, Savas O, Shaffer F (2011) Review of flow rate estimates of the Deepwater Horizon oil spill. Proc Natl Acad Sci USA 109:20260-20267

Montagna PA, Baguley JG, Cooksey C, Hartwell I, Hyde LJ, Hyland JL, Kalke RD, Kracker LM, Reuscher M, Rhodes ACE (2013) Deep-sea benthic footprint of the Deepwater Horizon blowout. PLoS One 8:e70540

Murawski SA, Hogarth WT, Peebles EB, Barbeiri L (2014) Prevalence of external skin lesions and polycyclic aromatic hydrocarbon concentrations in Gulf of Mexico fishes, post-Deepwater Horizon. Trans Am Fish Soc 143:1084-1097

Nash UA and Randall M (2015) GIS determination of the area of high-profile ( $>2$ m elevation) reef-top biotope within the Pinnacles polygon- based on USGS high resolution multibeam sonar acoustic backscatter data acquired in 2000. USGS Coastal Ecology and Conservation Research Group, Gainesville, FL. Internal Briefing to NRDA TWG, 21 April 2015. 23 pp

NOAA (2010) Oil spills in coral reefs: planning and response considerations. In: Yender RA, Michel J (eds) US Department of Commerce, National Oceanic and Atmospheric Administration. Silver Spring, MD, pp 2-82

NOAA (2014) Cumulative TCNNA SAR Oiling - Days of Oiling, Environmental Response Management Application. Web application. ERMA Deepwater Horizon MC252. National Oceanic and Atmospheric Administration. Accessed 30 Jan 2015. http:// response.restoration.noaa.gov/erma/

Passow U, Ziervogel K, Asper V, Diercks A (2012) Marine snow formation in the aftermath of the Deepwater Horizon oil spill in the Gulf of Mexico. Environ Res Lett 7:035301

Peccini MB, MacDonald IR (2008) Correspondence of sea fan orientations with measured currents on hard bottom habitats of the Mississippi/Alabama continental shelf. Cont Shelf Res 28:302-308

Peters EC, Meyers P, Yevich P, Blake N (1981) Bioaccumulation and histopathological effects of oil on a stony coral. Mar Pollut Bull 12:333-339

Prytherch HF (1983) A descriptive survey of the bottom longline fishery in the Gulf of Mexico. NOAA Technical Memorandum NMFS-SEFC-122:1-33 
Rezak R, Bright TJ, McGrail W (1985) Reefs and Banks of the Northwestern Gulf of Mexico: their geological, biological, and physical dynamics. John Wiley and Sons, New York

Ribes M, Coma R, Gili JM (1999) Heterogeneous feeding in benthic suspension feeders: the natural diet and grazing rate of the temperate gorgonian Paramuricea clavata (Cnidaria; Octocorallia) over a year cycle. Mar Ecol Prog Ser 183:125-137

Sampaio I, Braga-Henriques A, Pham C, Ocana O, De Matos V, Morato T, Porteiro FM (2012) Cold-water corals landed by bottom longline fisheries in the Azores (north-eastern Atlantic). J Mar Biol Assoc UK 92:1547-1555

Sánchez JA, Ardila NE, Andrade J, Dueñas LF, Navas R, Ballesteros D (2014) Octocoral densities and mortalities in Gorgona Island, Colombia, Tropical Eastern Pacific. Int J Trop Biol 62:209-219

Scott-Denton E, Cryer PF, Gocke JP, Harrelson MR, Kinsella DL, Pulver JR, Smith RC, Williams JA (2011) Descriptions of the U.S. Gulf of Mexico reef fish bottom longline and vertical line fisheries based on observer data. Mar Fish Rev 72:1-26

Sherwood OA, Heikoop JM, Scott DB, Risk MJ, Guilderson TP, McKinney RA (2005) Stable isotopic composition of deep-sea gorgonian corals Primnoa spp.: a new archive of surface processes. Mar Ecol Prog Ser 301:135-148
Silva M, Etnoyer PJ, MacDonald IR (2015) Coral injuries observed at mesophotic reefs after the Deepwater Horizon oil discharge. Deep Sea Res Part II Top Stud Oceanogr. doi:10.1016/j.dsr2. 2015.05.013

Sulak K, Berg J, Randall M, Dennis III GD, Brooks RA (2008) Dualcarbon sources fuel the OCS deep-reef community, a stable isotope investigation. Proc 11th Int Coral Reef Symp 2:945-949

Trygonis V, Sini M (2012) photoQuad: a dedicated seabed image processing software, and a comparative error analysis of four photoquadrat methods. J Exp Mar Biol Ecol 424:99-108

Valentine DL, Fisher GB, Nelson RK, Reddy CM, Sylva SP, Woo MA (2014) Fallout plume of submerged oil from Deepwater Horizon. Proc Natl Acad Sci USA 111:15906-15911

Weaver DC, Dennis GD, Sulak KJ (2002) Community structure and trophic ecology of demersal fishes on the Pinnacles Reef tract. USGS BSR 2001-2008

White HK, Hsing PY, Cho W, Shank TM, Cordes EE, Quattrini AM, Nelson RK, Camilli R, Demopoulos AWJ, German CR, Brooks JM, Roberts HH, Shedd W, Reddy CM, Fisher CR (2012) Impact of the Deepwater Horizon oil spill on a deep-water coral community in the Gulf of Mexico. Proc Natl Acad Sci USA 109:20303-22030 